\title{
Decadence and occulture
}

Oscar Parviainen's art

DOI: https://doi.org/10.30664/ar.98066

Attribution 4.0 International (CC BY 4.0)

$\mathrm{T}$

his article contributes to the understanding of relations between occulture and Decadence in Finnish art at the turn of the twentieth century, focussing on occulture and Decadence in the works of the Finnish artist Oscar Parviainen (1880-1938). The aim is to understand what are the relations between Parviainen's art, the Decadent art movement and occulture, and what are the aspects and cultural phenomena of his time that share similar lines of thought as Parviainen? In which ways did Parviainen address questions of higher truths about human existence, and what kind of role did they play in his thinking?

\section{Introduction}

Oscar Parviainen (1880-1938) was a Finnish artist whose career extended from the late 1890 s to the early 1930s. Parviainen grew up in a wealthy and cosmopolitan family in Helsinki. Against his family's expectations he started to pursue the career of an artist and studied at a number of art schools, the École des Beaux-Arts in Paris to name just one, but did not finish at any of them. Despite his notable education, personal relationships with the art world elite, and his extensive production of interesting works, he never became a distinguished figure in the Finnish art scene or its art-historical canon, which is partly a consequence of him hardly ever entering into exhibitions or selling his paint- ings, combined with his tendency to stay for long periods of time abroad. All this - the travelling and a reluctance to sell his works, was largely made possible by family wealth and his inheritance. It is important to acknowledge here that he was not bound by the same economic realities as most artists; also that his health was poor throughout his life, due to inherited heart problems and chronic tendency to lung disease (Waenerberg 1996).

Parviainen's art was, especially during the 1910s, somewhat bleak, but also in some manner spiritual. This article tries to understand what aspects of culture might have affected this. Therefore, I will analyse Parviainen's art in the context of Decadence and occulture - the connection to these themes is in many cases the philosophy of Arthur Schopenhauer (1788-1860). It has been suggested that themes of death in Parviainen's work are influenced both by events in his own life and the prominent Symbolist painters that preceded him, but also by the philosophy of Schopenhauer (Waenerberg 1999 passim). Schopenhauer was one of the most important philosophers to inspire Decadent artists and was one of the first western philosophers to come to similar conclusions as some eastern religions and is therefore relevant to the 
subject (see e.g. Pierrot 1981: 55-60). I will return to Schopenhauer later.

Parviainen is not known to have been involved in any esoteric movements. To what extent Parviainen was aware of esotericism and its most prominent movements at the time, is unclear. As Annika Waenerberg notes when mapping out Parviainen's art's intellectual influences, Theosophy was a common subject of conversation among his close colleagues, such as the artists Bruno Aspelin (1870-1941) and Akseli Gallen-Kallela (1865-1931) (Waenerberg 1996: 108), and, continuing this thought, I must assume he was at least aware of them, on the basis that similar lines of thought were so popular and widespread in turn-of-the-century artistic circles, especially in Symbolism (see e.g. Sarajas-Korte 1966: 51-4; Lahelma 2018: $32-5)$. Nonetheless, because of the uncertainty of his level of knowledge on the subject, specific movements or texts of esotericism are not the main focus of this article, which focuses on the concept of occulture instead.

With the term occulture I refer to a diverse milieu of spirituality that formed around esoteric discourses, as characterized by Nina Kokkinen in her dissertation about occulture and modern spirituality in turn-of-the-century Finnish art, and its three notable artists Hugo Simberg (1873-1917), Akseli Gallen-Kallela and Pekka Halonen (1865-1933) (Kokkinen 2019: 44). To be more precise, the concept has been formed in the study of religion to emphasize the importance of the milieu which forms around groups that are typically more loosely formed and tend to have shorter lifespans. Such groups include not only esoteric communities such as the Finnish Theosophical Society or small groups gathering around Spiritualist séances, but also artistic circles such as the
Zum schwarzen Ferkel which met in Berlin during the 1890 . In this milieu the esoteric discourses of higher knowledge and truth had a crucial significance (Kokkinen 2019: 44-52; Kokkinen 2013: passim).

Parviainen's artistic themes revolve around questions of life and death, love and agony, and the (spiritual) truths behind them. To understand these explorations, it is useful to turn our focus away from mainstream religion, since it does not seem to explain Parviainen's art adequately. Kokkinen notes that when esotericism is understood in terms of a set of discourses considering the pursuit of higher knowledge and truth, artistic and scientific conversations can be equally a part of it. Literature circulated and contributed to these discourses, and is therefore considered to be a constituent of occulture (Kokkinen 2019: 52). This article will focus on such considerations by analysing Parviainen's art in the context of lines of thought such as Schopenhauer's pessimistic philosophy, and the ideology and writings prevalent in artistic circles like the ones mentioned above.

As I will later show, Oscar Parviainen did seamlessly incorporate religious, scientific, and philosophical ideas into his art. I present the connections between Parviainen's art and the ideas of esoteric movements where I see a strong enough resemblance, but even then, I do not claim there to be a direct link between them: he might have sourced the ideas indirectly or just copied them from elsewhere without a clear understanding of their connections to esotericism. When addressing larger questions, I will lean on the concept of occulture. Parviainen was part of these discourses; he was both influenced by them and a contributed to them himself.

'Decadence', as in the Decadent art movement of the fin-de-siècle, and 'deca- 
dence' as an adjective cannot really be separated, since the origins of the movement intertwine with the discourse of decline in the late nineteenth century. In this article the terms are separated by use of the upper-case $\mathrm{D}$ when it refers to the phenomenon in the arts. What is now known as Decadence was formed in European literature and spread to the visual arts before the century was over. Jean Pierrot (1981) summarizes the elusive nature of the aesthetic of Decadence in his The Decadent Imagination $1880-1900$ as follows:

It is based, firstly, on a somewhat pessimistic conception of human existence, seen as subject to the pitiless necessities of a physical, physiological, and social determinism that holds man in thrall to the laws of heredity, the species to those of evolution, and the exceptional individual to the law of the majority, decreed by democracy. Religious faith has ceased to be anything other than a nostalgic memory; love is merely an unconscious subjection to an instinct aimed solely at the survival of the species. Nature, far from being the attentive and responsive witness conceived by the romantics, is an unfeeling and pitiless mechanism. The best thing for us to do therefore, surrounded by such anguish and sadness, though not without a certain feeling of guilt, is to attempt to escape from that nature, to reject biological laws of our species as far is possible, and to hold ourselves aloof from society. (Pierrot 1981: 9-10)

Even though Pierrot's understanding of Decadence is a bit outdated, it still serves as a good layout of its aesthetic. In a recent study, Nordic Literature of Decadence (Lyytikäinen et al. 2020), Decadence is understood as a 'constellation' of movements (situated between romanticism and modernism) which share some similar traits, such as an interest in decay and the end-times and an antipathy towards modernity. By rejecting the idea of Decadence as a 'movement' per se, the study aims to understand the meaning of Decadence in a broader context. It considers the sense of decay as the defining sensibility of Decadence. It also highlights three categories in Decadence: decadent naturalism, 'core' decadence (i.e. Central European, canonized Decadence), and the 'afterlife' of these in later literature (ibid. passim) As my goal is to approach similar themes in Decadence and consider Decadence in a similar manner, I adopt this approach in this article. In the case of the visual arts, this does not radically change the iconographical understanding of Decadence from, for example, Pierrot's older and narrower definition, but has an important impact on the possibilities of conclusions. Furthermore, such wider understanding of Decadence is even more important in the field of visual arts, since its Decadence is such an abstract concept: it lacks - if we discount the two or three main artists, which hardly can be considered to amount to a canon - even a vague and arguable, but widely-known literary canon, 'core decadence' as referred to above. To summarize my understanding of Decadence then: firstly, I would present it as a collection of counter-cultural features: it was anti-modern, anti-naturalist and against the bourgeoisie sensibility; secondly, as a phenomenon of culture, I do not consider it to be a movement, or artists simply either being or not being a part of it.

'Decadence' had an ambivalent meaning in nineteenth-century culture as well: on the other hand, it was a pejorative term, used to slander an opponent, but some took it proudly as their own. As mentioned 
above, where Decadence in literature is somewhat hard to pinpoint, this is even more so the case in the field of visual arts: often the themes familiar in Decadent literature are addressed in the visual arts as a part of Symbolism (Nissen and Härmänmaa 2014: 4-5). Some have stated that in literature Symbolism succeeded Decadence and others that Symbolism was the visual equivalent of Decadence (see e.g. Pierrot 1981: 5-9), but my attempt here is not to clarify the nature of their conjunction, but to address the questions stated above therefore I will maintain a wide perspective on what Decadence actually is; my understanding of it is both thematical, that is to say I consider Parviainen's art Decadent when I see thematical resemblances to Decadent literature in it, and theoretical, when I see a correlation between the causes of 'core Decadence' and Parviainen's art.

Pierrot's definition succeeds in grasping some aspects of the Decadent worldview, but when considering the influence esotericism had on Decadence, he undermines it, and states that esoteric movements were too vague and inconsistent to attract wide interest among decadent poets and, by implication, painters (Pierrot 1981: 11718). As mentioned earlier, this is not the case. Per Faxneld, who has researched both Decadence and esotericism extensively, writes in his dissertation that the relation of the Decadent movement to religion is impossible to define as it varies greatly among the artists, and therefore needs to be addressed individually (Faxneld 2017: 261). This is what I aim to do in the case of Oscar Parviainen. Parviainen was reluctant to consider himself as a participant of any particular movement or (what he perceived as) style and said 'I do not understand how someone could paint while being a part of some group with a coherent style' (Tirranen 1950: 253), ${ }^{1}$ but as I will later show, the influence of the Decadent aesthetic is clear in his work. As already stated, his religious views are unknown, and there is no clear evidence of him being a part of any esoteric movement, but the influence of occulture will also be shown later. In addition to paintings, etchings, and drawings, I will use some written material: Parviainen wrote poems, theatre scripts and aphorisms. He never published, or even finished, these writings, and only fragments of them have been preserved, therefore it is hard to say anything conclusive about them. These materials are kept in Joensuu Art Museum, and since they are not systematically archived, I cannot provide proper references.

Salme Sarajas-Korte, a pioneer in studies in Finnish Symbolism, acknowledges Schopenhauer's influence in both French and German Symbolism, and by extension Finnish Symbolism, in her dissertation, and suggests that this is due to his pessimism, disdain of banalities, and high respect for artistic work (Sarajas-Korte 1966: 32). As Annika Waenerberg notes in her biography of Parviainen, he did read Schopenhauer (Waenerberg 1996: 108). In his main work The World as Will and Representation (first published in 1818) Schopenhauer presented a thoroughly pessimistic conception of the world, and of human existence, characterized by almost inescapable suffering. To briefly present Schopenhauer's basic ideas: in Schopenhauer's thinking, firstly, everything in universe is one and, secondly, everything in existence, from people to objects everywhere in the universe, is driven by a 'will to life' which causes

1 Finnish original: 'En ole koskaan ymmärtänyt, miten kukaan voi työskennellä kuuluen johonkin yhtenäistä ohjelmaa noudattavaan ryhmään. 
humans to endlessly strive for things; that is, to do anything is to follow this 'will to life. However, this striving never leads to satisfaction, since once a human achieves a particular goal, it immediately gets replaced by a new one. Often this striving is in contradiction with someone else's will to life, and therefore to strive is to reject someone else's will to life, and since everything is one, anyone's suffering is everyone's suffering. Therefore, the inescapable 'will to life' causes suffering which can't be prevented. One who lacks a goal to strive for gets bored, and in Schopenhauer's line of thought, to be bored is to suffer. However, art gives the opportunity to briefly escape this tormenting existence: Schopenhauer viewed great art, especially music, to be so powerful and captivating that it could occupy the human mind to the point that it would not have room for this 'striving.' As said, this has been seen as one of the key reasons why artists in the nineteenth century were so keen on Schopenhauer's ideas. Schopenhauer also set out a type of a person who would be free from this 'will to life': a 'sage' that would deny everything that has its roots in the 'will to life'- wanting, for example, good food, sexual relations, or wealth. This person would be in complete understanding of the situation explained above, and completely uninterested in the suffering around them, since they would know that they cannot do anything about it (for Schopenhauer's philosophy see e.g. Wicks 2008: passim). As I will show in this article these ideas repeatedly present themselves in Parviainen's art.

Schopenhauer's influence in art is widely recognized, his influence on Richard Wagner (1813-83) being the most commonly cited example (see e.g. Karnes and Mitchell 2020: passim). Schopenhauer wrote somewhat specific articles on music and how it should be, not the visual arts, but nonetheless, his views influenced visual artists as well: as mentioned, he viewed art as a way to escape the torment of existence, so it is easy to understand why artists would be keen on him, since 'his philosophy led to a morality based on salvation through art' (Pierrot 1981: 56). His pessimistic philosophy can also be considered to be closely linked to the Decadent aesthetic and sensibility (ibid. p. 6o). As already mentioned, this influence reached Finnish artists as well. Therefore, Parviainen's interest in Schopenhauer is not an isolated incident, but a part of broader interest amongst artists of the turn of the twentieth century.

Schopenhauer has its connections to esotericism. Already in The World as Will and Representation (1819/1909), he had reached similar conclusions as the eastern traditions and he acknowledged and embraced these similarities. As we know, many of the largest esoteric movements acknowledged eastern religious traditions as part of their doctrines. Robert Wicks has connected Schopenhauer's philosophy, especially the idea of the sage and ascetism, to the traditions of Christian Quietism, the Upanishads, and Buddhist ideas. To give some examples: Buddhism and Schopenhauerian thought share an idea of detachment as enlightenment, and Quietism has similar idea of resistance of desire, but the fact is that Schopenhauer did not distinguish between these traditions when referring to them (about Schopenhauer and esotericism, see Wicks 2008: 127-41).

Furthermore, it may be considered that even his style of writing is esoteric in its manner (Head 2020: passim); or more precisely in the tradition of pedagogical esotericism, that is, presented in such a way that something can be taught by first obscuring the answer and gradually revealing it to ensure the full and correct understanding (Melzer 2004: passim). This is a 
part of larger philosophical, theological and pedagogical discussion that there is no space here to address, but is referred to in order to illustrate how, as one notices when reading Schopenhauer, as a reading experience it can resemble that of reading a spiritual or religious text. However, the aim of this article is not to study Schopenhauerian thought itself, or its connection to esotericism, but to study how Oscar Parviainen might have incorporated it into his own thought and work. Schopenhauer can and should be seen as a part of occulture, - the milieu in which esoteric discourses were prevalent.

To summarize: above I have defined the context of this article; two phenomena relevant for an understanding Parviainen's art, especially during the 1910s, namely, occulture and Decadence. Neither of them has clearly defined delineaments, and should be understood to be discursive guidelines that presented themselves in the culture of the late 1800 s. Next, I will present their presence in Parviainen's art - to do so I have outlined three categories, mostly just for the sake of a clear structure.

\section{Death}

As the culmination of decay, death is a key subject in Decadent art and, to be more specific, the death aesthetic - both the death of beauty and the beauty of death itself (Nissen and Härmänmaa 2014: 3). Death in Parviainen's art, one of his most common subjects, has been analysed in earlier research as being the consequence of influence from his Symbolist predecessors such as Hugo Simberg and Akseli GallenKallela, whom he admired greatly, and partly as contemplation of and response to his own poor health (Tirranen 1950: 251). Even though this is possibly partly true, seeing these works as merely mannerist copies of Symbolist art, which was in the 1910s already somewhat passé, or as just meditations on one's medical condition is surely a somewhat thin view.

Some of Parviainen's death compositions, such as Skeleton Men (Döingarna, undated, Ateneum Art Museum), in which skeletons march like an army with skeleton dogs at their feet and playing violins are bleak and intimidating; but not all of them are so, such as the painting Crypt of the Capuchin Friars (Kapusinernas gravkammare, 1914, Joensuu Art Museum). Here we see an interior covered with skulls and four skeletons, two standing in dark brown robes and two lying in recesses in the walls, with two burning candles in front. It depicts the crypt beneath the Santa Maria della Concezione dei Cappuccini church in Rome, as can be discerned from the signature which also indicates 'Rome'. In Crypt of the Capuchin Friars the atmosphere is more serene. Nina Kokkinen has shown in her dissertation that monks were a somewhat common subject among Finnish Symbolists and were connected to the esoteric mentality: they were a part of an artist's self-image, as exemplified in works by Gallen-Kallela and Simberg. The monk represented a truth-seeking hermit, deeply focused on his work and above the banalities of the common people - qualities that the artists wanted to see in themselves as artists (Kokkinen 2019: 123-33). I believe this to be also the case with Parviainen the reason why he visited the crypt in Rome in the first place and why he painted this grand, almost three-metre-wide painting.

We know that his artistic practice incorporated elements from this hermit ideal: during his most intense painting periods he secluded himself from others and worked manically day and night, secluding himself from social contact and daily life, much like the Capuchin monks. He also stated himself that painting should be done 


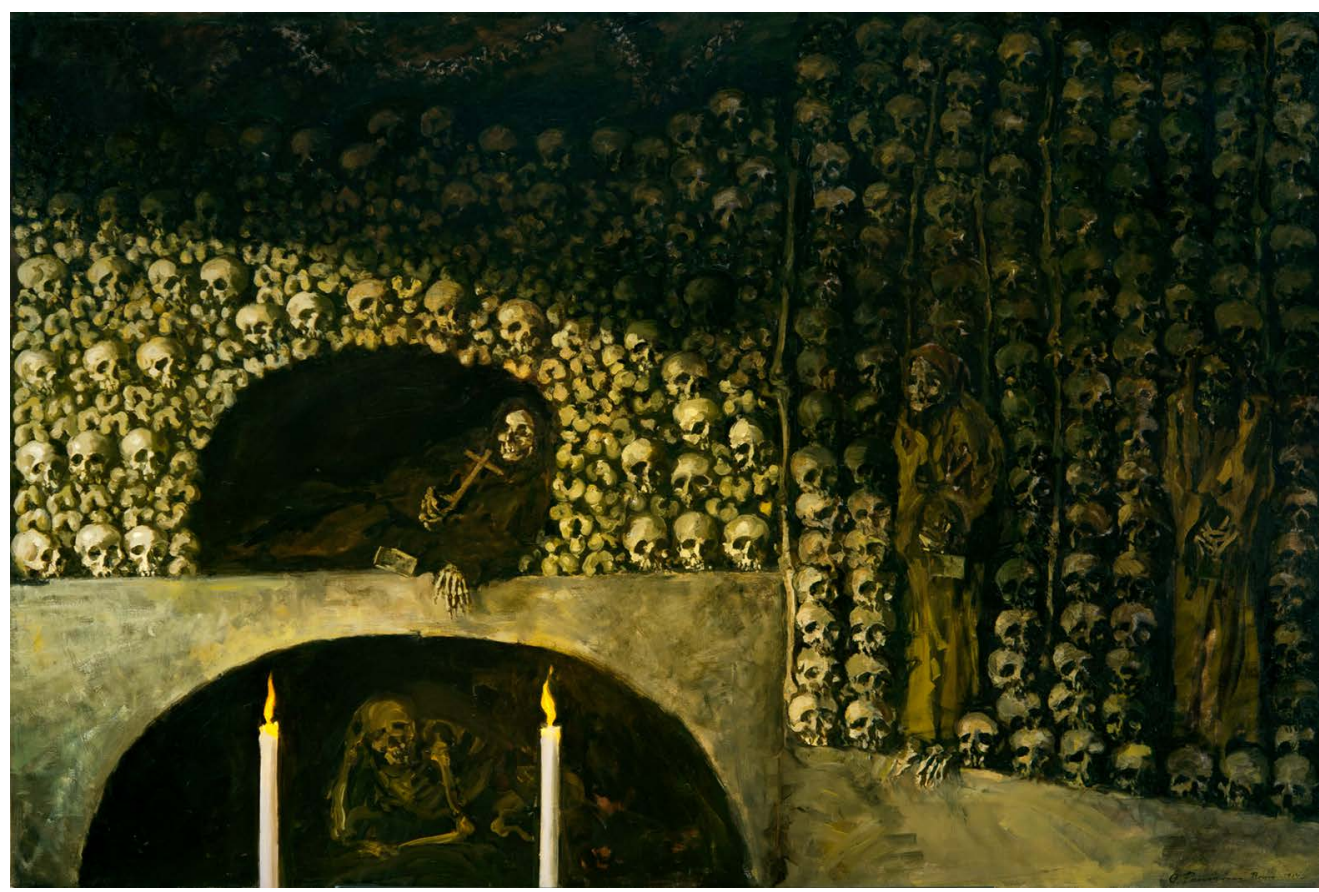

Oscar Parviainen, Crypt of the Capuchin Friars, 1914, oil, 198 × 295 cm, Joensuu Art Museum.

Photo: Joensuu Art Museum.

when 'the spirit takes over' ('andan faller öfver en') and only then. He also distinguished artists, himself included, that were 'dreamers and migratory birds' ('drömmare, konstnärer o snillrika flyttfåglar') from 'potato people' ('potatismänniskorna'), that failed to lift themselves any higher than the ground level (Waenerberg 1996: 40). Thus, this ideal of monks also starts to recall Schopenhauer's 'sage', the pinnacle of human existence. In the third volume of The World as Will and Representation Schopenhauer states, when explaining imagination's value to a genius, that: 'The man who is endowed with imagination is able, as it were, to call up spirits, who at the right time reveal to him the truths which the naked reality of things exhibits only weakly, rarely, and then for the most part at the wrong time' (Schopenhauer 1909: 142). Parviainen seems to have shared this idea of how great art is produced.

Parviainen's artistic self-image was formed of religious and mystical themes, mixed with bohemian elements that he encountered when studying in Paris during the first decade of the twentieth century (Waenerberg 1996: 41). In 1907 Parviainen moved to Båtstad on Lake Vitträsk, a secluded villa, with an atelier, some 30 kilometres from Helsinki. The image of a hermit-like artist battling with grand questions was already how some of his contemporaries saw him - in the 1930s he was described as a hermit-artist who produced 'intoxicating night visions' (Waenerberg 1996: 110). His working method caused some worry among his friends and family: the intense periods of painting that occasionally included heavy drinking took a toll on his already poor health (ibid. pp. 150-4, 1813). Therefore, Parviainen's artistic identity resembles ideals common in occulture and bohemian Decadence: a Schopenhauerian genius, above the banalities of modern life and secluded from it in his villa, as 
in Crypt of the Capuchin Friars, where he chooses to express themes common in esotericism in terms of its bleakest, most decayed form, as dead brothers of the Capucian order, not as serene wandering hermits and Jesus-like characters as had his Finnish predecessors and objects of admiration such as Gallen-Kallela and Simberg.

One death motif stands out: a small drawing depicting a butterfly rising from its cocoon surrounded by human skulls. The work is titled The Symbol of Immortality (Odödlighetens symbol, undated, Joensuu Art Museum archives), and is accompanied by a poem: 'Death solves the dark riddle of life / Lets the soul rise free from its cocoon / mortals, stop crying / you will soon be butterflies yourself'.2 The theme of the drawing is resurrection, but from what tradition it has been derived is unclear. Resurrection has its meaning in various religious doctrines, also in Christianity (see e.g. Ferguson 1981: 13). As the poem indicates, death is seen as a salvation, a thing that sets one's soul free from earthly boundaries and a reason why the living should not be worried, since death is inevitable but positive.

In her article about Parviainen's death motifs Annika Waenerberg notes that in Symbolism, and in the case of Parviainen, the Christian tradition does not solely suffice as their explanation; one observation she makes on Parviainen's death motifs, which have their roots in dance macabre, is that the focus seems to shift from what is the destiny of all humans to how life is seen now, while it is happening: it seems to be a moral suggestion to live better by asking 'is this it?' (Waenerberg 1999: 98-107). The

2 Translated by author from original Swedish: 'Döden loser livets mörka gåta / Låter själen fri ur puppan gå / Hören upp i dödliga att gråta / Snart i ären Fjärilar också.'
Symbol of Immortality seems to work in the same realm, it speaks directly to the living and reminds them to view their lives from the perspective of death - and find comfort in it. This is done by using the idea of metamorphosis, symbolized quite explicitly by a cocoon and a butterfly, presenting death as a transmutation into something better. The image is Decadent by nature: it presents a glorified and aesthetic death, and the poem, in which all mortals are crying helplessly, also seems reminiscent of a pessimistic understanding of human existence in the Schopenhauerian manner.

As we see from the examples above, Parviainen's death motifs have similarities with both the aesthetics and the worldview of Decadence and ideas common in esotericism: they should not be understood as being expressions either of Decadence, esotericism, or mannerist Symbolism, but to incorporate aspects of them all. Some of Parviainen's visions of death and the skeleton men that bring it were horrible and took their inspiration from fear of death and war, but he also saw hope and beauty in it. It was a part of his self-image, and also included a possibility of regeneration. For Parviainen death was deeply personal, both mysterious and horrible, yet also beautiful and liberating.

\section{Sexuality}

Parviainen's paintings which conjoin sexuality and suffering seem to clearly recall Schopenhauerian concepts. For Schopenhauer, love was a ruse of the 'will to life' to get people to reproduce as, clearly, no person in their right mind would take up caring for a child. To love and lust for someone was again just a thing to strive for, a manifestation of the 'will to life' and it would inevitably lead to disappointment. Therefore, to love is to be in a state of constantly shifting between desire and being 


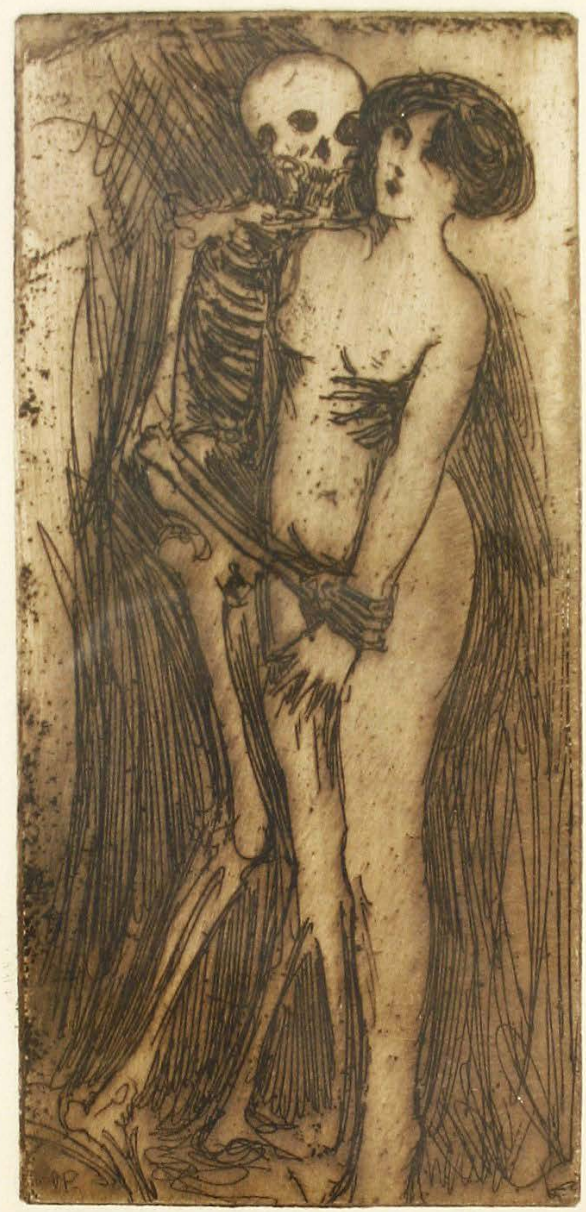

Oscar Parviainen, In Death's Grasp, c.1906, etching, $16,5 \times 8 \mathrm{~cm}$, Joensuu Art Museum. Photo: Mikko Välimäki.

bored. Schopenhauer's ideology is known to have affected the Polish author Stanislaw Przybyszewski (1868-1927) (Sarajas-Korte 1966: 308), who was a key figure in Zum schwartzen Ferkel and was one of the most prominent diabolical figures of the fin de siecle (Faxneld 2012: 55-9). The way that Parviainen conjoins death and eroticism is similar to Przybyszewski's Decadent eroticism; the themes themselves were not new at the time, since conjoining erotic female nudes with Death has been a well-known motif since, for example, the sixteenthcentury German renaissance, where they served as vanitas themes and aimed to remind everyone of the evanescence of earthly beauty and pleasure - to give an example, the resemblance between Parviainen's In Death's Grasp (Dödsgreppet, c.1906, Joensuu Art Museum) and Hans Baldung Grien's (1480-1545) Der Tod und Das Mädchen (1517, Kunstmuseum Basel) is apparent.

However, in the late nineteenth century there was a widespread idea of an evil sexuality, of deviance and its dangers, that took the form of the femme fatale, and was deeply intertwined with the misogynistic views and gender morality of European societies, Finland included (Välimäki 2019: passim), but here the focus is on the Decadents' interest on the motif of the dangerous woman, death and eroticism as a component of their worldview, philosophy and aesthetics. As Per Faxneld argues, in Przybyszewski's system, women were the diabolical sex, the Devil, but in the positive sense. In his line of thinking, Satan and evil were progressive, and therefore the women that symbolized them had a positive meaning. This was, among other things, a way to make it clear that they did not share the ideology of Christianity or the bourgeois (Faxneld 2017: 320-5). Therefore, the Devil, and the women linked to it, could, in the context of Satanism and Decadence, be viewed as the basis of political statements. Referring to Pierrot, Faxneld mentions that these gender views were inspired by the misogyny of Schopenhauer (and Baudelaire) (ibid. p. 269). Waenerberg mentions the gender norms of pessimistic philosophy as a source of inspiration for Parviainen (Waenerberg 1999: 103).

Schopenhauerian ideas, we know, 


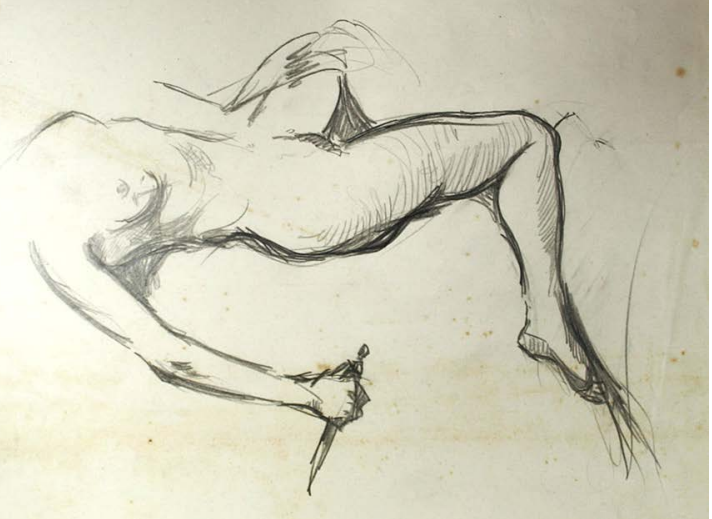

Oscar Parviainen, sketch to The End, c.1910, drawing, Joensuu Art Museum. Photo: Mikko Välimäki.

Parviainen read himself, but to what extent he was aware of Przybyszewski's texts is unclear. He might have encountered them for example through Akseli Gallen-Kallela. Salme Sarajas-Korte mentions that some of his most notable Symbolistic paintings are fully understood only when taking the influence of Zum schwartzen Ferkel into account; she especially sees a direct connection between the gender relations of Przybyzsewksi's ideology and GallenKallela's Conceptio Artis (1894) (SarajasKorte 1966: 305-10; see also Kokkinen in this issue). Even if the texts themselves, such as the article Przybyszewski wrote about Edvard Munch, and which GallenKallela read sometime during the 1890 , did not reach Parviainen he was at least under the influence of the Symbolism influenced by them. Parviainen and GallenKallela were acquainted from at least 1905 onwards, when their letter correspondence begun: Parviainen and the composer Jean Sibelius sent Gallen-Kallela a letter from Paris in 1905 (Sarajas-Korte 1966: 269), and another letter, where he shows the deep admiration he felt for him and expressed his wish to learn from him, was sent sometime during first decade of the twentieth century (Waenerberg 1996: 86).

Parviainen produced several works with these themes. The End (Slutet, 1910, Joensuu Art Museum) depicts a naked young woman lying on a pedestal motionless and unconscious - dead, as the title suggests - surrounded by skeletons that seem to tend to the deceased. It is, firstly, a beautiful death, a painting that evokes the sadness and anguish caused by death, but also sensual lust. Secondly it is a picture about the death of beauty, a female figure objectified in a way reminiscent of the rotting fruits found in earlier vanitas themes. The dagger in her hand, which is hardly visible but can be clearly seen in the sketches, reveals the woman to be a beautiful Death as well, a Death in female form. On the surface, the painting seems to represent a decadent Olympia, a modern demi-mondaine woman, but wrapped in death. A woman on the altar had already been depicted in turn-of-the-century Satanic iconography: Felicien Rops's (1833-98) Le Sacrifice from Les Sataniques (1882) depicts this motif with a Satanic figure above her having intercourse. The altar has a female skeleton figure masturbating with bone, and there are two skeleton puttis flying above the woman.

A similar theme is presented in JorisKarl Huysmans's (1848-1907) La-Bas (1891), when Des Hermies, an acquaintance of the protagonist Durtal, describes a black mass of medieval Satanism: 'On a table serving as tabernacle a woman lays down, naked or with her skirts lifted up over her head, and with her arms outstretched', and continues to explain how the Sacraments were served on either the woman's abdomen or buttocks (Huysmans 2001: 54-6). Faxneld notes that the same theme is present in $\grave{A}$ rebours (1884) as well, when the protagonist Des Esseintes cites 
the fifteenth-century book on witchcraft Malleus maleficarum (Faxneld 2017: 305). Parviainen's paintings do not quite reach the grotesqueness of Rops or Huysmans, but these or similar subjects - Decadent aesthetics - could explain this somewhat abnormal painting. As for Schopenhauerian or Przybyszewskian ideas, The End creates them only in the audience, not in the paintings itself. The woman or the skeletons are neither in pain nor experiencing pleasure, but for the person watching it, it can induce both; it caters to the Decadent sensibility perfectly, not least because of its Satanic connotations which can be seen as part of occulture.

I understand Satanism here in the same sense as Per Faxneld when he speaks of it sensu lato: in his dissertation he states that 'Satanism' can be used either, in a strict sense, 'a system in which Satan is celebrated in a prominent position', or in a broad sense (sensu lato) as a discursive strategy, as praise of various ideas, without forming the whole worldview or spirituality around Satan, even if making Satan a prominent figure. Faxneld also wants to exclude those who refer to or applaud Satan in a very sporadic manner (Faxneld 2017: 25). Even though there is no evidence that Parviainen was a Satanist in a strict sense, or even believed in such a deity, he can be considered a Satanist in a sense that he did repeatedly use the idea of Satan or Lucifer in his work. Satanism has its connections to both Decadence and esotericism. ${ }^{3}$ Therefore, it is relevant to this article.

3 The relation between esotericism and Satanism has been debated and it can be questioned if Satanism should even be studied in parallel with esotericism. As this article's goal is to understand the occulture behind Parviainen's art, Satanism, that is an important part of this discourse in his case, should be taken into consideration.
Diabolical sexuality is a part of the etching Death Biting a Snake (Döden biter orm, 1904, Finnish National Gallery). The connection to sexuality can be detected in the form of the snake, a symbol of sin as derived from Genesis and furthermore of the fille d'Eve, a concept in cultural history where all women could be seen as daughters of Eve and prone to the same kind of deviant tendencies (see e.g. Menon 2006: passim). In art history we see this in artwork where the Fall of Man theme has been reduced to a young naked woman and a snake, possibly without any other reference to the Bible; no tree or apple, in Finland (Välimäki 2019: 27-35). Parviainen's etching is an eclectic mix of iconography including the skull from the vanitas themes and Symbolism and the snake from religious themes and its modern adaptations. The conclusion, however, is an etching with indications of pain, fear, salaciousness, and pleasure, all hallmarks of, for lack of a better expression, Satanic sexuality.

To give one more example, in Blindfold Game (Blindbock, undated, Joensuu Art Museum) a blindfolded satyr tries to catch the nymphs that surround him. Here the focus is not on death, but in an erotic game where the naked nymphs, which have strong seductive but also potentially dangerous qualities, tease the blindfolded satyr or Pan, characters closely related to Satanism and popular in, for example, German Symbolism, Zum schwartzen Ferkel, and the art magazine Pan (SarajasKorte 1966: 310-15). Here the sexual game is, in a very explicit manner, a shift between frustration and fulfilment. In this context, a relevant similarity can be found in the views of women laid out by Schopenhauer and especially Karl Hartmann (1862-1906) - like Schopenhauer, a pessimistic philosopher - who stated that women were driven by instinct, and that they were in essence 


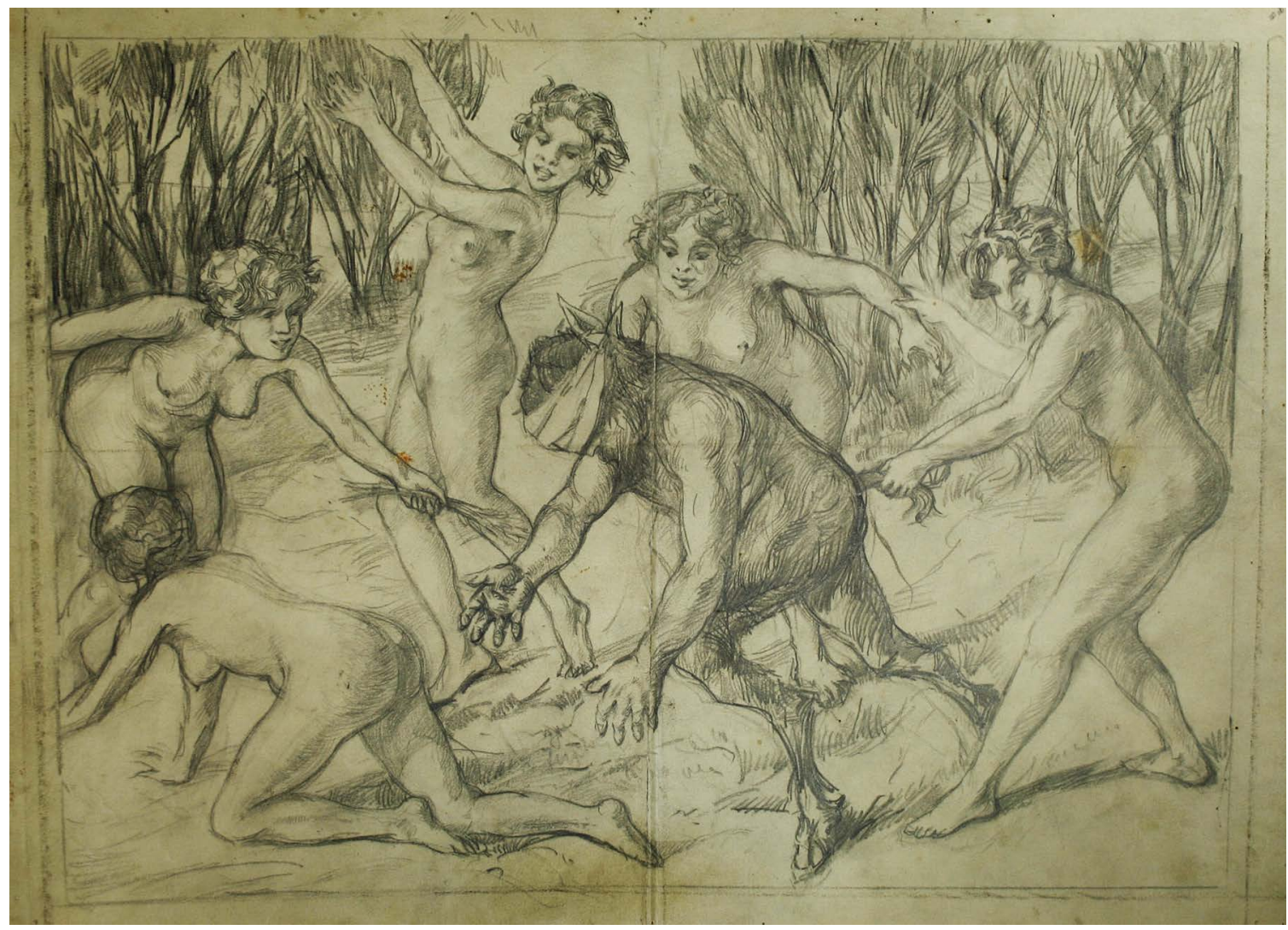

Oscar Parviainen, Blindfold Game, undated, Joensuu Art Museum. Photo: Mikko Välimäki.

merely a part of nature (about Parviainen's views on women and pessimistic philosophy, see Waenerberg 1966: 183). In this context the nymphs of Blindfold Game would be symbols of women in this most primal state, teasing but not quite giving themselves to man - a symbol of sexuality as intriguing but unsatisfying, much as Schopenhauer claimed it to be.

Lucifer was a rebellious figure both in Satanism and esotericism. For the Decadents Lucifer was a figure of resistance against the banalities of modern life and the bourgeoisie, for the esoteric an opposition to God as traditional religions understood the deity (Faxneld 2017: 255-6). A somewhat common idea has been that the Decadents used the image of Lucifer mostly to shock their audience, to tease the hated bourgeoisie, and that the idea of Lucifer as a benevolent figure of resistance was not so important (ibid. p. 264). Helena Petrovna Blavatsky (1831-91), a key figure in modern esotericism and the co-founder of Theosophical Society, was one of the first to include an appraisal of Satan into esotericism in the same manner as had been done previously in the context of literature and politics. By doing so she influenced greatly esoteric movements that formed Satanic doctrines after her. Faxneld mentions that also Przybyszewski was probably influenced by Blavatsky's notions of Satan (Faxneld 2013: 225). Therefore, when trying to map out the context of Parviainen's Satanic themes, we notice that in this case in some points, the 'decadent' and 'esoteric' influences, overlap. 


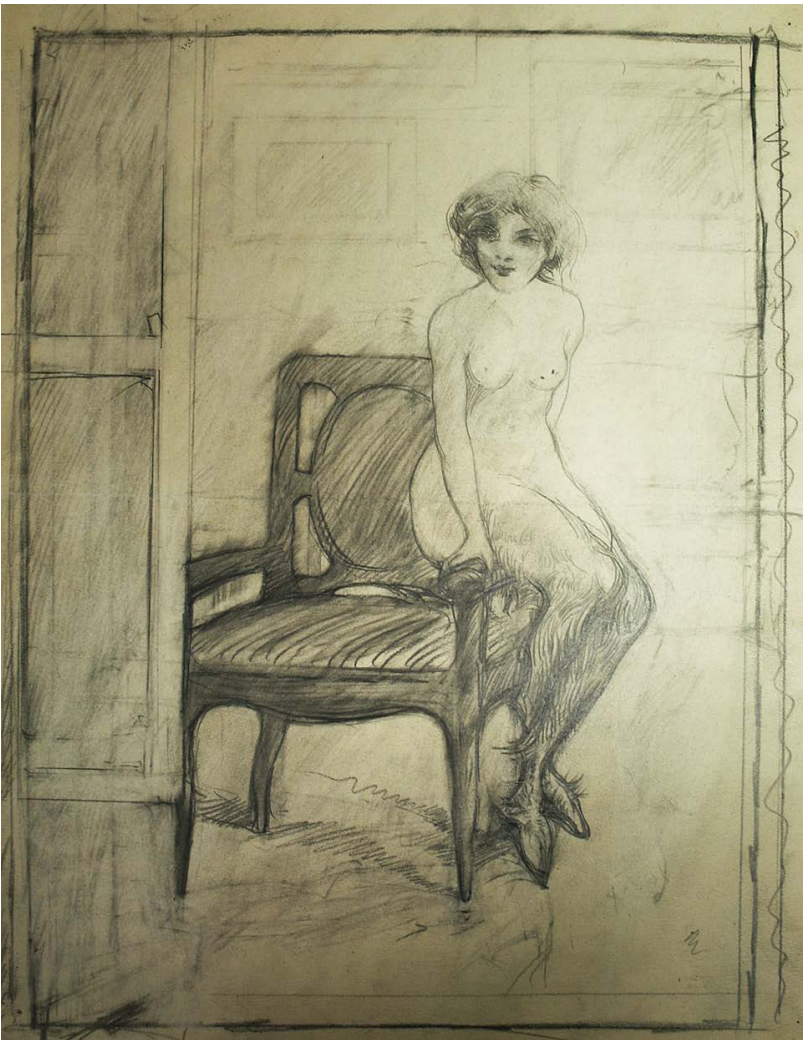

Oscar Parviainen, Female Satyr on the Arm of an Armchair, undated, Joensuu Art Museum. Photo: Mikko Välimäki.

Faxneld concludes his article by noting that Blavatsky's 'Satanism' (he does not suggest that she is a Satanist in a strict sense), even whilst being preliminarily religious, is filled with political implications and is a didactic manoeuvre (Faxneld 2013: 227). This would also include the same political strategies and ideas that Satan represents in Decadent form of thought.

There are a few explicit Satan figures in Parviainen's drawings, that did not lead to larger works. One is a drawing entitled Satan and God (Satan o Gud, undated, Joensuu Art Museum), that simply depicts the two characters next to each other. There are a few textual fragments concerned with the devil, for example one where the devil himself speaks: 'I am a ruler, a real King / a majesty ha ha ha, ha ha.... ${ }^{4}$ In this and other text fragments the devil seems to be more like the character in Decadent literature than the benevolent rebel of doctrines of esotericism. However, when Blavatsky discusses Satan in the 'Secret Doctrine' she perceives Satan and God to be parallel, 'twin brothers of the same mother', and as inseparable - she does so by referring to, for example, Kabbalistic and old pagan ideas (Blavatsky 1888/2019: 411-24). The drawing by Parviainen, where the two entities, Satan and God, sit together, might be considered to include a similar thought: two figures in equality, no clear division of good or evil, just two sides of the same coin.

The drawing Female Devil (Kvinnojävel, undated, Joensuu Art Museum) is minimal in content as well, but could have a connection to the gender views and Satanism of Przybyszewski. The naked female figure sits in a modern interior, and therefore could be understood as a modern woman, and not some mythological motif. The modern woman, sexuality and Satanic imagery is well presented also in the drawing Female Satyr on the Arm of an Armchair (Kvinnlig satyr på stolarmen, undated, Joensuu Art Museum), where a naked woman with goat hooves sits in an interior, perhaps atelier or an art gallery where there are several drawings or paintings on the wall behind her. From these two drawing we can conclude, that in some sense, Parviainen conjoined the figures of a woman and the Devil. Therefore, Parviainen, Zum schwartzen Ferkel, Przybyszewski, and Huysmans had similar ideas on gender and Satanism.

I would suggest that as in the works of art presented above, Satan was a recurring and important figure for Parviainen. The Satanic themes were not the ones that he

4 Swedish original: 'Jag är en härskare, en riktigt Kung / en majästet ha ha ha, ha ha.... 
put on display for the general public, and therefore cannot be understood as a way to merely 'shock the audience', but perhaps more as way for himself to build his own identity, to separate himself from his background and to connect himself to the bohemian art scene. Soili Sinisalo has written that 'He [Parviainen] tried in some manner to make his whole life as art. It was typical that his style of dress was pedantic and attracted attention for its elegance and eccentricity. During the heat of July, he might be seen promenading in Helsinki in a white suit. When with his friends, he liked to wear oriental dresses' (Sinisalo 1980: 6-7, my translation). Here he reminds Joris-Karl Huysmans's Des Esseintes, the protagonists of his book A rebours, and the archetype of a Decadent dandy (see e.g. Faxneld 2017: 270).

\section{Apocalypse}

Parviainen made several depictions of the end of the world. Their inspiration seems to come from the biblical stories, but also from the scientific discoveries of the nineteenth century. They manifest as fantastical visions of the apocalypse, that have no explicit single origin, but many. The merging of the biblical and profane and the ancient and the modern are not uncommon: Przybyszewski tied his Satanism to the theory of evolution and social Darwinism (Faxneld 2017: 267), and it has been argued that the whole idea of 'decadence' can be traced to the natural sciences and to the philosophy of history (Morley 2004: passim).

The first of two large-scale dystopian scenes is The End of the World (Var jords slut, early 1910s, Joensuu Art Museum). Its subject is annihilation on a grand scale: there are two mountains in front, covered with yellowish human figures piling on top of each other and falling down the steep walls of the mountains into a red ocean of human figures at the bottom. The sea of corpses seems to continue beyond the horizon. The yellow planet, presumably Saturn, shines in the sky. In a Christian context, the closest theme would be from the Book of Revelation (16:1-21), where the sea turns to blood, the biggest earthquake ever seen by man strikes, and the great city splits into three. This is the final destruction, the end of the world, an end stage before the Kingdom of Heaven that arises after the annihilation in the form of New Jerusalem; a sort of cleansing destruction, a mandatory stage of suffering on the road to happiness. There were similar interests in esotericism: reincarnation was an important part of development, and it required death in the process (e.g. in Theosophy see Boag 2011: passim).

Another painting with a connection to a biblical story is Paradise (Paradiset, 1910, Joensuu Art Museum), which combines the biblical paradise, the Garden of Eden, with the theory of evolution and reptiles. The painting depicts a well-kept garden, where two reptiles, perhaps dragons or dinosaurs, wander around. Parviainen had many paradise themes connected to the Book of Genesis, Adam and Eve and The Fall of Man, but this stands out, since it does not have any apparent link to the biblical stories. However, such liberal depictions inspired by biblical origins were quite common in Finnish Symbolism, and they had a connection to esotericism, Satanism and Decadent poetry, which I have no space here to discuss (see Sarajas-Korte 1966: 171-4). The aspect of occulture that I want to address here is that the painting seems to mix two rival explanations of human existence: the scientific and the religious. By replacing Adam and Eve in the Garden of Eden with reptiles, Parviainen seems to side with the scientific version, or at least 
play with that idea. In Parviainen's notes there is a fragment about paradise where he reflects on how one cannot ever enter paradise, due to one's evilness, hatred, vengefulness and so forth (Waenerberg 1996: 11214). In his thinking people are not good enough to access paradise, and hence the paradise of his painting that has no people, only these peculiar reptiles, seems apt.

Struggle of the Last Men (De sista människornas kamp, 1914, Joensuu Art Museum) depicts a formation of somewhat abstract human figures rising from the ground and reaching to the sky from a blueish ground littered with bodies. From the sketches it comes apparent that it took inspiration from Gericault's Medusa's Raft: Gericault's and Parviainen's paintings have strikingly similar compositions, and the sketches even include the ship in the horizon. However, Parviainen's finished work lacks the sea and the raft, and seems to have moved onto dry land. Therefore, it becomes more reminiscent of Edward Munch's

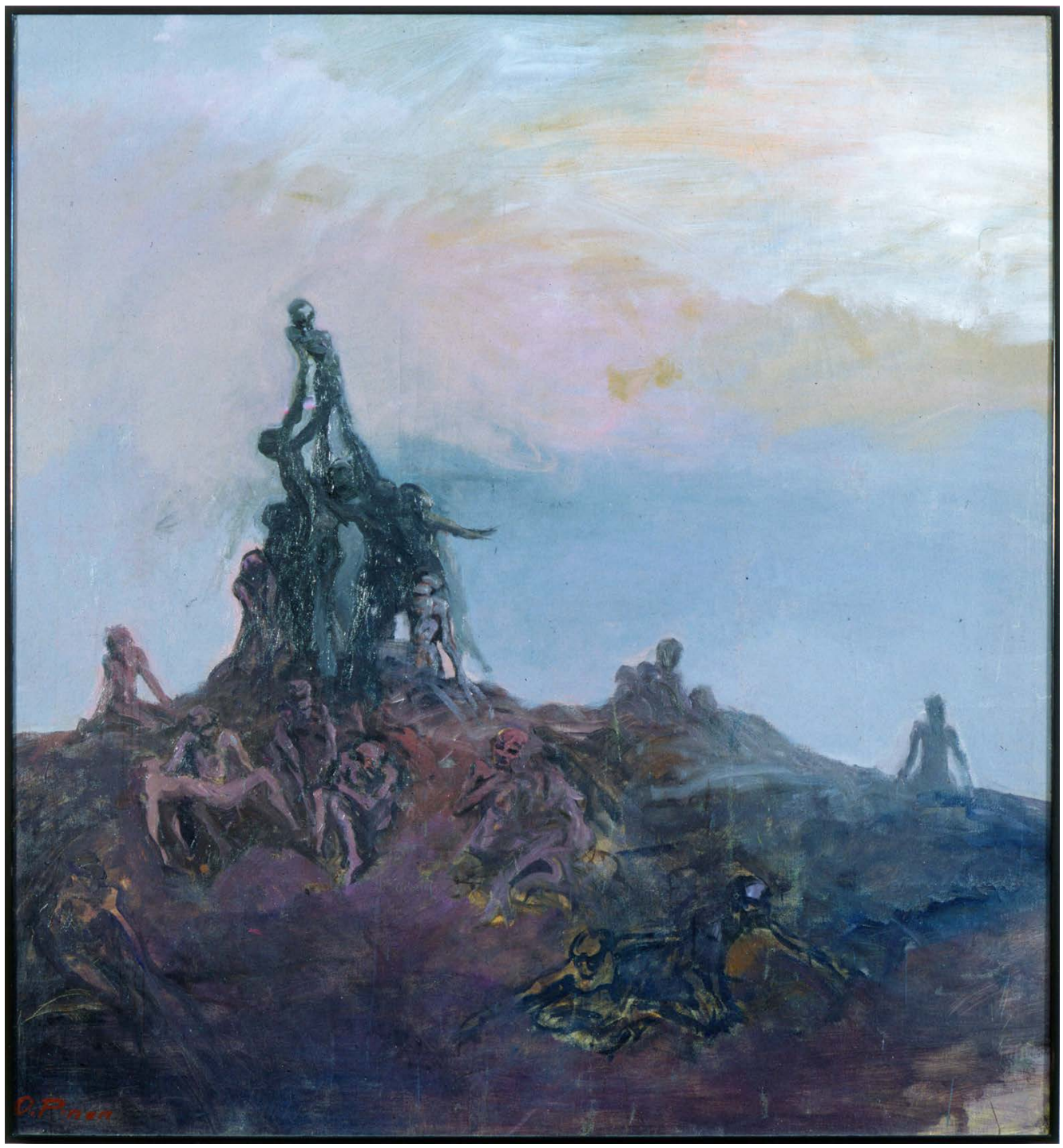

Oscar Parviainen, Struggle of the Last Men, c.1913-14, Joensuu Art Museum. Photo: Joensuu Art Museum. 
many human-mountain themed works of art, linked with Friedrich Nietzsche's Thus Spoke Zarathustra (Waenerberg 1996: 115-18). Here one might find connection to Schopenhauer and pessimistic ideology (since Schopenhauer's influence on Nietzsche is widely known), but since Parviainen's paintings do not really depict a mountain, and we do not know if he read Nietzsche, the analogy would rest on a weak basis.

A similar theme can be found in H. G. Wells's The Time Machine (1895), where at the end of the book the time traveller, after visiting the distant futures deeply decadent remains of a failed society, ends up in the barren wasteland of an entropic end of the world. Wells's novel has been analysed as being inspired by the new discoveries in the field of thermodynamics, more precisely the inescapable heat death of the universe, where the expanding universe in which new energy, heat, is not being produced, eventually cools down to below lifesupporting levels (Tattersall 2014: 26-9). The landscape of this heat death in Wells's novel is a cool and slowed down seashore. It has a lot in common with the blueish agony of Parviainen's The Struggle of the Last Men. Therefore, if The End, or even Paradise seem more religious or spiritual, the Struggle of the Last Men seems secular. However, I suggest that occulture is a relevant context for these three paintings too: so that we can understand the at first confusing mix of scientific, artistic and philosophical influences mentioned above as a part of the same discourse of a pursuit of a higher understanding of fundamental truths of human existence. Kokkinen has noted that in fin-de-siècle occulture the borderlines between science, pseudo-science, knowledge and belief were not understood in the same way they are today (Kokkinen 2019: $52)$. It seems that when forming his visions of the beginnings and the end of humanity, Parviainen took inspiration equally from science, and the fields that are now separated as science and pseudo-science.

To take Schopenhauer again into consideration, we notice that once more apocalyptic themes fit well into picture. Schopenhauer thought that non-existence was better than existence, as he states in his chapter 'On the vanity and suffering of life' (Schopenhauer 1909: 382-402) - by implication, Schopenhauer seems to indicate that it would have been better if the world had never been originated. Parviainen's paintings do not necessarily celebrate the end, but neither does Schopenhauer: there is a difference in never having come to existence and in ending one's own existence. Nevertheless, some of Parviainen's paintings do include the liberatory aspect of the apocalypse that one would expect from a Schopenhauerian ending of everything, and therefore it could be considered a factor in them. Furthermore, I would suggest that the interest in both the apocalypse and Schopenhauer are coherent characteristics in a person.

In the examples above I have shown that Parviainen's apocalyptic themes vary greatly in their content and possible origins. As they are quite uncommon in Finnish art, and seem to lack apparent textual or visual origins, we should consider their connection to Decadent art movement and its influence. These Decadent visions might well have a connection to ideas common in esotericism and even more so to scientific and philosophical ideas of the late nineteenth century. It seems that both the death motifs as well as the apocalyptic themes can be interpreted as contemplations on the possible cathartic dimension of death. Perhaps the artist looked to derive comfort from these subjects in his own personal struggle with his 
health, but they took a somewhat grim form because of the Decadent quality of his psyche. All in all, occulture seems to be a useful concept when trying to understand Oscar Parviainen's work.

\section{Conclusion}

At first, I expected to find the reason for the 'inexplicable' spirituality in Parviainen's art from some particular esoteric movement, but this turned out not to be the case. Or at least I did not find clear connections. However, the concept of occulture seemed to be more useful: Parviainen's spiritual themes were influenced by, and contributed to, the esoteric discourses of his time. The philosophy of Arthur Schopenhauer and Satanism, particularly as manifested in the Decadent art movement, are a relevant context, and a large component of the spiritual level of his paintings and etchings.

The relationship between Decadence and occulture is not a simple one. Occulture refers to the milieu formed around esoteric discourses of higher truth and wisdom, whilst Decadence is best described as a sensibility concerning certain themes and the constellation of movements that shared them. Therefore, in some sense they are similar: non-coherent groups of people that share an interest in a higher understanding of the world around them. Yet, Decadence must be understood from the viewpoint of the European artistic tradition of the 1800 s, and occulture as a methodological apparatus designed to study the spiritual landscape of a given entity. Therefore, the similarities, although useful, can be misleading when applied as closely as I have done in this article.

In Parviainen's art Schopenhauer's philosophy seems to be a recurring factor and a relevant context as an underlying concept of human existence that influences works of art that connect with both Decadence and the spiritual. These manifest themselves most prominently in works depicting death, sexuality, and the apocalypse. To claim Parviainen's art is influenced by Theosophical or other esoteric movements directly, a more thorough knowledge of Parviainen's first-hand knowledge of them should exist. Perhaps they were not completely alien to him, as they had such a prominent position in his context, but analysing individual works of art from a theme derived from texts of esotericism is purely hypothetical. In a broad sense, I believe this article demonstrates that Parviainen's work very likely includes an influence of esotericism, whether this came to him directly through its texts, or through the influence of his associates.

Furthermore, even if the Decadent is easier to pinpoint, it cannot be separated from the spiritual and religious contemplations that can be repeatedly seen in his work, well exemplified in Crypt of the Capuchin Friars. Decadence and many of its themes have a spiritual dimension - death can hardly be romanticized without including some sense of spirituality, as at least Parviainen did when he included metamorphosis, personification of Death, and the afterlife. Decadence and esotericism share similar themes, and the same art historical subjects and iconographical themes are used to treat both interests, quite clearly presented in Parviainen's death motifs. Typically, the motifs in this article also serve as ways to build an artistic identity: an exceptional genius, bohemian and more than usually capable of transcendental contemplation, who rises above the masses and the bourgeoisie. Since Parviainen uses Decadent iconography to address life's biggest questions (life and death, life after death, the essence of humanity, love, suffering, and himself and his place in the world) I would consider 
its use as somewhat hallow. In several cases, Zum schwartzen Ferkel, Stanislaw Przybyszewski, and Satanism seem relevant in the case of Oscar Parviainen and Finnish Decadence in general.

As shown above, even though I have mainly focused on deconstructing the themes of Parviainen's art, and separating their connections to Decadence, occulture and esotericism - categorizing that might seem trivial - this article contributes to the understanding of how these phenomena are intertwined, how it can be studied, and what are the possible themes that can be assumed to have these connections.

Mikko Välimäki, MA, is an art historian and a doctoral student in the University of Helsinki. His doctoral thesis considers the Decadent art movement in Finland, and notions of decline in Finnish culture. The main focus of his research is on the history of ideas, cultural history and the dominant morals of Finnish society at the turn of the twentieth century.

\section{Bibliography}

Blavatsky, Helena. 1888/2019. The Secret Doctrine, vols. I-II (Pasadena: Theosophical University Press).

Boag, Al. 2011 'From Blavatsky to Krishnamurti: Hindu chronology, biblical eschatology, physiology', Literature \& Aesthetics, 21(1): 116-34.

Faxneld, Per. 2012. 'Witches, anarchism, and evolution: Stanislaw Przybyszewski's finde-siècle Satanism and demonic feminine, in The Devil's Party: Satanism in Modernity, eds. Per Faxneld and Jesper Aagaard Petersen (Oxford University Press), 53-77.

- - 2013. 'Blavatsky the Satanist: Luciferianism in Theosophy, and its feminist implications', Temenos: Nordic Journal of Comparative Religion, 48(2): 203-30.
- 2017. Satanic Feminism: Lucifer as the Liberator of Woman in Nineteenth-century Culture (New York: Oxford University Press), doi: $<10.1093 / 050 / 9780190664473.001 .0001>$.

Ferguson, George. 1981. Signs \& Symbols in Christian Art (Oxford University Press).

Head, Jonathan. 2020. 'Speculation and esotericism in Schopenhauer's philosophy', Il Pensare, 9: 153-75.

Huysmans, Joris-Karl. 2001. The Damned (New York: Penguin Books).

Karnes, Kelvin C., and Andrew J. Mitchell. 2020. 'Schopenhauer's influence on Wagner', in The Oxford Handbook of Schopenhauer, ed. Robert Wicks (Oxford University Press), doi: <10.1093/ oxfordhb/9780190660055.013.27>.

Kokkinen, Nina. 2013. 'Occulture as an analytical tool in the study of art', Aries, 13(1): 7-36, doi: <10.1163/15700593-01301003>.

- 2019. Totuudenetsijät. Vuosisadanvaihteen okkulttuuri ja moderni henkisyys Akseli Gallen-Kallelan, Pekka Halosen ja Hugo Simbergin taiteessa (University of Turku).

Lyytikäinen, Pirjo, Riikka Rossi, Viola ParenteČapková, and Mirjam Hinrikus. 2020. Nordic Literature of Decadence (New York and London: Routledge).

Melzer, Arthur. 2004. 'On the pedagogical motive for esoteric writing', The Journal of Politics, 69(4): 1015-31, doi: <10.1111/ j.1468-2508.2007.00604.x>.

Menon, Elizabeth. 2006. Evil by Design: The Creation and Marketing of the Femme Fatale (Urbana-Champaing: University of Illinois Press).

Morley, Neville. 2004. 'Decadence as a theory of history', New Literary History, 35: 573-85, $<$ www.jstor.org/stable/20057861> (accessed 8.9.2020).

Nissen, Christopher, and Marja Härmänmaa. 2014. 'The empire at the end of Decadence', in Decadence, Degeneration, and the End, eds. Christopher Nissen and Marja Härmänmaa (New York: Palgrave Macmillan), 1-14.

Pierrot, Jean. 1981. The Decadent Imagination: 1880-1900 (The University of Chicago Press).

Schopenhauer, Arthur. 1819/1909. World as Will and Idea [orig. Die Welt als Wille und Vorstellung, 1819], trans. R. B. Haldane and 
J. Kemp (London: Kegan Paul, Trench, Trübner \& Co. Ltd.).

Sinisalo, Soili. 1980. Oscar Parviaisen 100vuotisnäyttely: 7.12.1980-4.1.1981 Joensuun taidemuseo (Joensuu: Karjalaisen Kulttuurin Edistämissäätiö).

Tattersall, Mason. 2014. 'Thermal degeneration: thermodynamics and the heat-death of the universe in Victorian science, philosophy, and culture', in Decadence, Degeneration, and the End, eds. Christopher Nissen and Marja Härmänmaa (New York: Palgrave Macmillan), 17-34.

Tirranen, Hertta. 1950. Suomen taiteilijoita Juho Rissasesta Jussi Mäntyseen. Elämäkertoja (Porvoo: WSOY).

Välimäki, Mikko. 2019. 'Kaunis kuin synti. Femme fatalen kulttuuriset merkitykset 1800- ja 1900-lukujen vaihteen kuvataiteessa', master's thesis (University of Helsinki).

Waenerberg, Annika. 1996. Parviaisen matkassa. Oscar Parviainen 1880-1938 (Joensuu: Joensuun taidemuseo).

- - 1999. 'Kuoleman kuvat ja Oscar Parviaisen taide', in $A B O A$ 1995-96 (Turku Provincial Museum). 